\title{
Teachers' old-fashioned classroom practices: A pitfall on the use of digital technology in mathematics teachings
}

\author{
Dwi Ratnasari ${ }^{1}$, Kamirsyah Wahyu, Sofyan Mahfudy ${ }^{2}$
}

\begin{abstract}
Abstrak: Penelitian ini bertujuan menganalisis bagaimana guru pemula menggunakan teknologi digital dalam kelas dan perubahan praktik pembelajaran setelah menggunakan teknologi. Dua guru matematika SMA menjadi subjek dalam penelitian. Subjek merupakan guru pemula terkait penggunaan teknologi digital dalam pembelajaran matematika. Data utama penelitian diperoleh melalui rekaman video pembelajaran. Hasil wawancara dengan guru dan catatan lapangan digunakan sebagai data pendukung. Video pembelajaran dikelompokkan menjadi beberapa episode, dibuat transkrip dan dianalisis berdasarkan langkah-langkah analisis rekaman video dan transkrip pembelajaran oleh Cobb and Whitenack (1996). Untuk memperoleh gambaran menyeluruh praktik guru, analisis data merujuk pada kerangka orkestra instrumental (Drijvers et al, 2010) dan segiempat didaktik terbuka (Hollebrands \& Okumuş, 2018). Penelitian ini menemukan bahwa sebagian besar orkestra guru dalam pembelajaran masih bercirikan pembelajaran tanpa teknologi. Dua guru dalam penelitian ini memiliki fokus yang berbeda dalam pembelajaran yaitu fokus hanya pada matematika dan fokus pada matematika melalui penggunaan teknologi. Hasil penelitian tersebut menunjukan bahwa praktik rutin guru tanpa teknologi bisa menjadi hambatan dalam pembelajaran berbasis teknologi.
\end{abstract}

\section{Kata kunci: GeoGebra, Tugas matematika, Teknologi digital, Hambatan, Praktik Guru}

\begin{abstract}
The research aimed to analyze how novice teachers use digital technology and transform their practices from without-technology to with-technology mathematics teachings. Two upper secondary mathematics teachers were involved in this research. They were novice teachers in the use of digital technology in mathematics teachings. Classroom video recording and transcripts were the primary sources of data, meanwhile interview with the teachers and field notes are the supporting data. The teachings videos were categorized into some episodes, transcribed and analyzed following the phases of analyzing classroom video recordings and transcript by Cobb and Whitenack (1996). To capture the whole picture of the teachers' practices, data analysis was referred to instrumental orchestration (Drijvers et al., 2010) and didactics tetrahedron unfolded (Hollebrands \& Okumuş, 2018). In this research, we found that the observed teachers' orchestrations are mostly nontechnology orchestrations. The teachers have a different focus; one focuses only on mathematics and another focus on mathematics through the use of technology. The research concludes that oldfashioned classroom practices can be the pitfall for using digital technology in the mathematics classroom.
\end{abstract}

Keywords: GeoGebra, Mathematics task, Digital technology, Pitfall, Teachers' practices

\section{A. Introduction}

Mathematics teaching and learning is a complex process for which it involves the teacher, students and the content (mathematics). The three vertices in the didactic triangle come with its unique characteristics and yield complex interactions. It is not becoming less complicated when

\footnotetext{
${ }^{1}$ STMIK Bumigora Mataram, Mataram, Indonesia, dwi.ratnasari@stmikbumigora.ac.id

${ }^{2}$ Universitas Islam Negeri (UIN) Mataram, Mataram, Indonesia
} 
digital technology ${ }^{3}$ as another vertex reach mathematics classroom nowadays. To consider the roles of technology, some mathematics educators (Olive et al., 2010; Ruthven, 2012; Tall, 1986) extended the didactic triangle to a didactic tetrahedron (teacher, mathematics, student, and technology). Mathematics teachers play a central role to orchestrate the classroom practices so that the mathematics can be learned by the students effectively through or with the support of technology.

Researches in mathematics education concerning the use of digital technology have overgrown. It ranges from the students' use of technology and its effect on various aspects of learning (Aydos, 2015; Choi, 2010), mathematics teacher education (e.g. Doruk, Aktümen, \& Aytekin, 2013; Zengin, 2017), the practices of mathematics teachers with technology in the classroom (e.g. Brown, 2017; Hollebrands \& Okumuş, 2018) to teachers' professional development of using the digital technology (e.g. Drijvers et al., 2014; Rutherford, Long, \& Farkas, 2017). The findings of the researches have shown the success of the implementation by students or teachers (e.g.Olsson, 2017), the pitfall (e.g.Chan, Leung, \& Ong, 2016; De Villiers, 2006), challenges and opportunities the digital technology offers (e.g.Brown, 2015; ClarkWilson et al., 2014; Mukiri, 2016)

From all the accessions, mathematics teachers are in the central role. Drijvers (2015) place the teacher's roles as the first of three factors that support or hinder the use of digital technology in mathematics education. The other two are educational context and design. Fulfilling the roles of teachers to support the integration of digital technology in the mathematics classroom is not an easy task since they have to take into account the mathematical knowledge, knowledge about the artifact, didactic knowledge of mathematics, and didactic knowledge about the artifact (Tapan, 2003). Mathematics teacher should be able to use technology for designing mathematical activity and have own learning experiences with digital tools to establish technology-integrated knowledge (Laborde, 2007; Leung, 2016). Such requirements to effectively teach mathematics with or through digital technology emerge the question, how the novice mathematics teachers teach mathematics and change their practices in the classroom when involving digital technology?

Monaghan (2004) explored the practices of thirteen 'ordinary' mathematics teachers when using technology in the classroom from the lens of Saxe's four-parameter model, i.e., activity structures, prior understandings, conventions artifacts, and social interactions. Regarding the activity structures, the three teachers mimicked the cycle of non-technology lessons. The reasons for the unchanged practices were the teachers felt secure in following the established practices and were able to do this. Bozkurt and Ruthven (2015) compared a novice and expert teacher when using GeoGebra in teaching circle theorem. Drawing from the Structuring Features of Classroom Practice (SFCP) framework (Ruthven, 2009), the teachers had difference regarding the resource system, activity format and curriculum script. The novice teacher practices were still influenced by non-technology patterns and not fully instrumented by the technology. From the analysis of prior findings on teachers' practices when using technology in the classroom, Kendal (2001) had earlier confirmed that "...the ways individual teachers take up using technology in their mathematics classrooms is usually consistent with their normal teaching practices..."(p. 34).

Drijvers et al. (2014) investigated in which ways mid-adopting mathematics teachers with limited experiences using digital technology orchestrate technology rich-activities. The criteria

\footnotetext{
${ }^{3}$ Digital technology and technology are used interchangeably which refer to similar meaning
} 
of mid-adopting were the teachers who have taught less than 20 hours in a mathematics class with technology. Through the lens of instrumental orchestration (Drijvers, Doorman, Boon, Reed, \& Gravemeijer, 2010; Trouche, 2004), it is found that the six whole class orchestration suited most of the observed practices. Two new whole-class orchestrations emerged in the practices, i.e., the Guide-and-explain and the Board-instruction. The majority of observations was individual Guide-and-explain orchestration.

When mathematics teachers introduce technology in the classroom but still having a similar activity format or structures as regular lessons or without-technology (Bozkurt \& Ruthven, 2015; Kendal, 2001; Monaghan, 2004), this practice was identified as a pitfall. De Villiers (2006) explicitly argued that the apparent pitfall when digital technology used in the classroom is that rather than fundamentally changing teachers' traditional style of teaching, many of them use it as a glorified blackboard. Sutherland (2005) affirmed that teachers should use new technology in ways that transform mathematical activity. It enables the teachers doing mathematics which would not previously have been possible.

The researches (e.g., Bozkurt \& Ruthven, 2015; Drijvers et al., 2014; Monaghan, 2004) provide the initial and partial pictures how novice teachers teach mathematics with digital technology. We think it is partial in the context of describing the practices, the focus and the changes in the practices of the novice teachers. The initial and partial pictures should be further investigated to deepen our understanding and get the whole picture of how novice teachers use digital tools and transform their practices from without-technology to with-technology mathematics teachings. The current research aimed to address these two important cases. We argue that it is urgent to understand the practices of novice or mid-adopting teachers when using digital technology in the mathematics classroom for the design of digital technology-related teachers' professional development (TPD) programs.

The current research provides the whole picture of novice teachers' practices since we employed two essential frameworks, i.e., instrumental orchestrations (Drijvers et al., 2010) and didactics tetrahedron unfolded (Hollebrands \& Okumuş, 2018). The nature of each framework is very representative to achieve whole pictures of novice teachers' practices. The instrumental orchestration is a framework to describe observed teaching practices of implementing technology in the classroom (Drijvers et al., 2010). It thoroughly describes the configuration of teaching setting and the artifacts (didactical configuration), the exploitation of didactical configuration (exploitation modes), and didactical performance which break down into six orchestrations for whole class teaching and a seventh for students work individually or in pairs with technology. The teachers' orchestration on the artifacts, teaching setting, and their exploitation will reveal how the teachers orchestrate the teaching and change or transform practices from without-technology to with-technology mathematics teachings. The use of didactics tetrahedron unfolded aims to describe how teachers lead students' attention or teachers' focus when implementing a technology-based task (Hollebrands \& Lee, 2016).

\section{B. Methods}

Two mathematics teachers, MT1 and MT2, were the subjects in the research. MT1 has over eighteen years, and MT2 is over twenty-eight years experiences of teaching mathematics in upper secondary school. The teachers were two of the sixteen participants involved in two-day teachers' professional development (TPD) which aims to introduce GeoGebra and digital technology-based mathematics tasks. The two teachers were willing to continue using GeoGebra 
in their classroom accompanied by the researchers. Thus, the selection of the two teachers is on a voluntary basis. The topic of distances in solid geometry was chosen. Before teaching, the teachers designed the mathematics tasks relating to GeoGebra. The researchers only supported them in technical aspects of the tools since the teachers were just familiar with GeoGebra. The researchers did not intervene in the designed tasks. In the class of MT1, we have four lessons with the two topics, i.e., distance from the line to line and line to the planes in a cube. We have three lessons with MT2, and the topic was a distance from the line to line in a cube.

The subjects are novice teachers in the use of digital technology. They have just learned digital tools like GeoGebra and technology-related mathematical activities/tasks and not taught mathematics with technology. They have not used GeoGebra before the two-day workshop and classroom collaboration. Both teachers have sufficient content knowledge in teaching mathematics known from the test in the workshop, and their regular lessons pattern is quite similar. From the interview, we frame their typical ways of teaching.

Video recording of classroom teachings, interview with the teachers and field notes are the means of collecting the data. We observed and videotaped seven lessons of MT1 and MT2 using GeoGebra to teach the topic of distances in solid geometry (cubes). The analysis of the classroom videos adopted the phases offered by Cobb and Whitenack (1996). Firstly, the videos of MT1 lesson were divided into four episodes and three episodes for MT2 in chronological order which are similar to the number of the observed lessons. The seven episodes were transcribed to capture the details of teachers practices in using GeoGebra. Secondly, the episodes provided the initial conjectures that become the data which was analyzed to establish chronologies of teachers' instrumental orchestration (Drijvers et al., 2010) and teachers' focus (Hollebrands \& Okumuş, 2018; Hollebrands \& Lee, 2016). The conjectures were refined when analyzing the subsequent episodes. Thirdly, the inferences were made through the lens of the frameworks.

In the current research, the instrumental orchestration is defined as the teacher's intentional and systematics organization and use of the technological tool (GeoGebra) available in a technology-rich learning environment in a given mathematical task situation, in order to guide students' instrumental genesis (Trouche, 2004). There are six orchestrations for whole class teaching, i.e., Technical-demo, Explain-the-screen, Link-screen-board, Discuss-the-screen, Spot-and-show, Sherpa-at-work and a seventh (Work-and-walk-by) for students work individually or in pairs with technology (Drijvers et al., 2014).

Hollebrands and Lee (2016) used the didactic tetrahedron to develop four categories that can describe the focus of the questions, prompts, and statements exchanged between pre-service teachers (PSTs) and students while working on a technology-based mathematics task. The categories are the focus on technology, focus on technology to notice mathematics, focus on mathematics with the use of technology, and focus on mathematics. The four categories were portrayed on tetrahedron faces or called as didactic tetrahedron unfolded (Hollebrands \& Okumuş, 2018). The PSTs and the novice teachers involved in the current research have the same characteristics, i.e., have not used digital technology in the mathematics classroom. In this case, we adopted the four categories to investigate the teachers' focus when using GeoGebra to teach mathematics.

\section{Findings and Discussion}

This part will address findings and discussion of the findings. The findings focus on identified teachers' regular lesson without technology, the mathematics tasks used by the 
teachers, and teachers' practices of using GeoGebra which reveal the category of orchestrations and teachers' focus. The findings will be discussed through the lens of the frameworks and prior relevant researches.

The interview with the teachers and classroom observation before teaching with GeoGebra provide information on the teachers' typical ways of teaching mathematics or the activity format of regular lessons without technology. MT1 and MT2 do have a similar pattern of teaching mathematics without technology. The difference is that MT2 focus on individual work and the use of peer tutor. MT2 argued that students work individually when doing exercises/drilling will reveal their ability in mathematics rather than working in a group. The teachers' regular lesson without technology can be coded as this pattern; introducing the mathematics topics through lecturing or expository mode, providing and explaining worked examples, providing other problems as the exercises to be solved by each student but rarely in group, the students who solved the problems come forward to write and explain their works, teachers provide feedback on students' work or whole class closed discussion on the students' work and giving further problems as the homework. The activity format of the regular lesson does not differ a lot from the teacher involved in Hähkiöniemi (2013).

We draw three essential points regarding the teachers' regular lesson. Firstly, the lesson focus on drilling students to do the exercises. Thus, the focus is not developing understanding but the procedures to solve the exercises. Secondly, although the teacher facilitates the students to come up with different solutions and open up the discussion, it does not manage to develop and extend students' mathematics knowledge and understanding of the worked problems. Thirdly, the teachers do not design his/her mathematics task but directly use the tasks in the textbook. The tasks we mean in this context is information that serves as the prompt for student work, presented to them as questions, situations, and instructions that are both the starting point and context for their learning (Sullivan, Clarke \& Clarke, 2012). In this circumstance, we call the teachers' regular lesson as old-fashioned classroom practices.

The teachers designed the mathematics tasks related to the use of GeoGebra. We did not intervene in the task since we would like to examine the nature of their self-made task. We conducted a two-day workshop to introduce the GeoGebra and the digital technology-based mathematics task. However, due to the limited time of the workshop, we prioritized introducing the features of GeoGebra than the tasks. The sample of mathematics task 'Investigating cyclic quadrilateral' was also provided and discussed in the workshop adopted from Leung (2011). At the end of the workshop, the sixteen teachers worked in a group to design mathematics tasks. Figure 1 shows one of the tasks designed by a group to which the MT2 was the member. Figure 2 is the task designed by MT1 in the group.

Figure 3 and Figure 4 show the task designed by respectively MT1 and MT2 and used in the lessons. Figure 3(a) is the excerpt of tasks for the topic distance from the line to a line in solid geometry and Figure 3(b) is for the distance from the line to a plane. Figure 4 is the sample of tasks for the topic of distance from the line to a line in a cube.

Table 1 shows the highlight of four episodes of lessons by MT1. The two episodes for the topic 'distance of a line to line' and the remaining is for the distance of a line to plane topic. MT1 made five tasks for the first and the second topic. Table 2 shows the summary of three episodes of lessons by MT2. The episodes were used to teach the topic of the distance of a line to line. MT2 made three tasks for the topic. The teacher had introduced the features of GeoGebra 
Ratnasari, D., Wahyu, K., \& Mahfudy, S.

before the topics and asked the students to bring their laptop/netbook for the upcoming lesson (episode 1)

Learning objective

Determine the distance of a point to a point in solid geometry

Learning activities:

1. The students are given the problem

2. Draw a cube $A B C D$.EFGH in GeoGebra!

3. Place the point $R$ and $Q$ in the qube!

4. Determine the distance of point $R$ and $Q$ !

The problem:

Given a cube ABCD.EFGH with the edge $8 \mathrm{~cm}$.

The point $R$ is positioned in midpoint of diagonal plane ADHE,

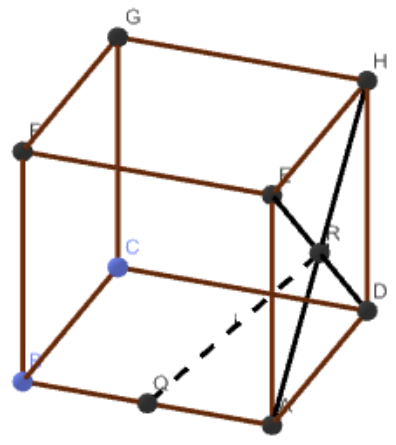

the point $Q$ is in the midpoint of line $A B$

Determine the distance of poin $\mathrm{Q}$ to the point $\mathrm{R}$ !

Figure 1. GeoGebra-related mathematics task4 designed by MT2 in group

The Position of Points to the Circle

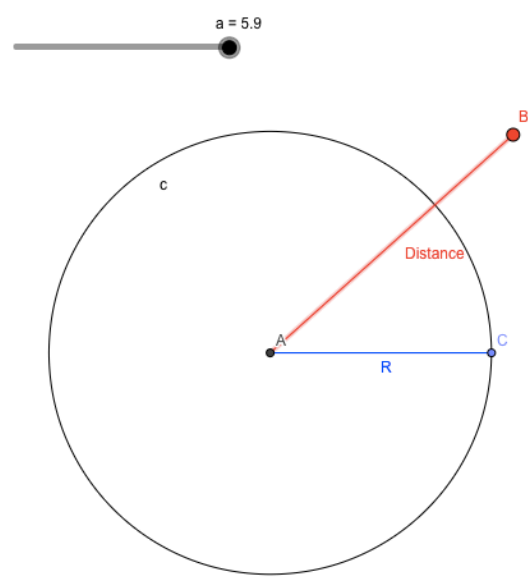

\begin{tabular}{|c|c|c|c|}
\hline \multicolumn{2}{|c|}{ The coordinate points } & \multirow{2}{*}{$\begin{array}{c}\text { Distance of point } A \text { to } \\
\text { point } B\end{array}$} & \multirow{2}{*}{ Radius } \\
\hline A & B & & \\
\hline$(\ldots \ldots, \ldots \ldots)$ & $(\ldots \ldots, \ldots \ldots)$ & & \\
\hline$(\ldots \ldots, \ldots \ldots)$. & $(\ldots \ldots, \ldots \ldots)$ & & \\
\hline$(\ldots \ldots, \ldots \ldots)$. & $(\ldots \ldots ., \ldots \ldots)$ & & \\
\hline$(\ldots \ldots, \ldots \ldots)$ & $(\ldots \ldots, \ldots . .)$. & & \\
\hline$(\ldots \ldots, \ldots \ldots)$ & $(\ldots \ldots, \ldots \ldots)$ & & \\
\hline$(\ldots \ldots ., \ldots \ldots)$. & $(\ldots \ldots ., \ldots \ldots)$. & & \\
\hline$(\ldots \ldots, \ldots \ldots)$. & $(\ldots \ldots, \ldots \ldots .)$. & & \\
\hline
\end{tabular}

Students' Activities:

1. Observe the point $B$ !

2. Compare the distance of point $A$ to the point $B$ in the circle while moving the slider!

3. Write your result of observation in the provided table!

4. Draw a conclusion refering to the table!

Figure 2. GeoGebra-related mathematics task designed by MT1 in group

Task 1:

Given a cube $A B C D . E F G H$ with the edge $4 \mathrm{~cm}$, calculate the distance from:
a. Line $E H$ to line FG
b. Line $\mathrm{EH}$ to line $\mathrm{BC}$
c. Line $A H$ to line $B G$
d. Line $E H$ to line $C G$
e. Line $A E$ to line $F H$

${ }^{4}$ The original task is in Bahasa then translated in English

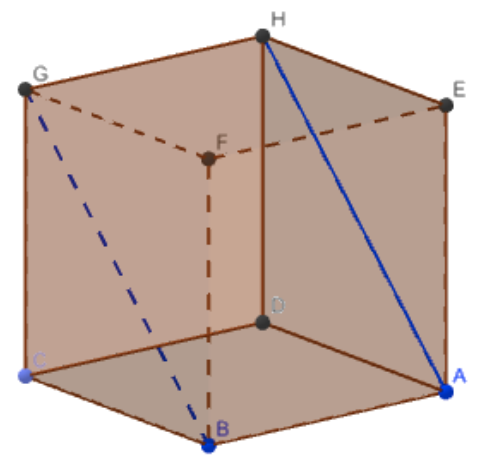


(a)

\section{Task 2:}

Given a cube $A B C D . E F G H$ with the edge $4 \mathrm{~cm}$, calculate the distance from line $\mathrm{BD}$ to plane $\mathrm{AFH}$ !

(b)

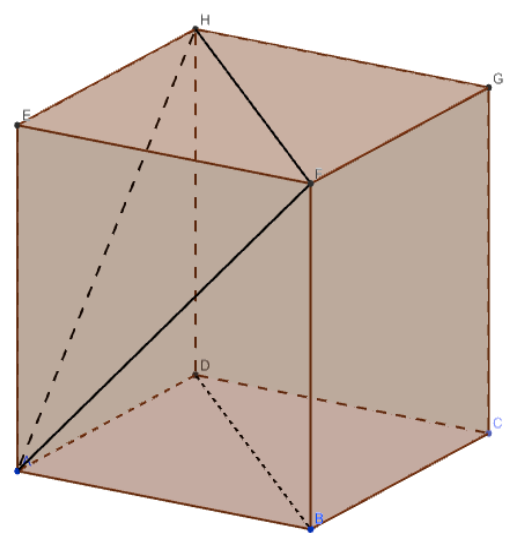

Figure 3. GeoGebra-related mathematics task designed by MT1

Task 2:

Given a cube ABCD.EFGH with the edge $6 \mathrm{~cm}$, Show in GeoGebra and determine the distance of line $P D$ and line FQ manually!

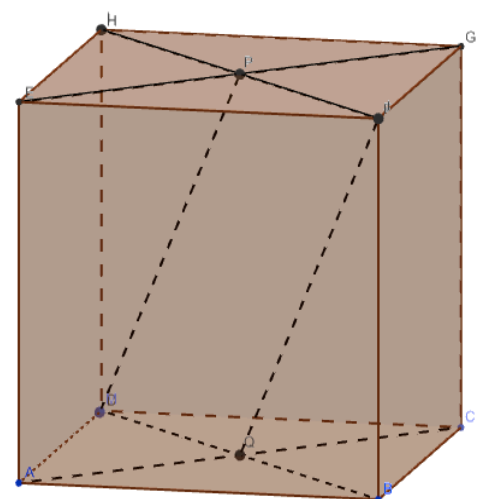

Figure 4. GeoGebra-related mathematics task designed by MT2

Table 1. MT1 lessons with GeoGebra

Teaching
episodes $\quad \begin{gathered}\text { Teacher's practices } \\ \text { Episode 1 }\end{gathered} \quad \begin{aligned} & \text { The teacher drew a cube on the board then explain the distance of a line to } \\ & \text { made in GeoGebra (Figure 3.a) through the projector (one screen) and } \\ & \text { explained the (a) to }(d) \text { in a teacher-centered manner. The students only respond } \\ & \text { to some questions related to the task posed by the teacher. } \\ & \text { The teacher invited the students to solve the (e). A student came forward } \\ & \text { and wrote his answer on the board. The teacher asked the students whether or } \\ & \text { not they understand the work of their mate. Some students' response indicates } \\ & \text { that they understood. The teacher clarified some steps on the student's work. } \\ & \text { The teacher then proceeded to task 2. Before asking the students to solve } \\ & \text { the task 2, the teacher shortly reminded the students that the two lines are } \\ & \text { perpendicular. A student came forward to write his work on the board. However, } \\ & \text { the work was halfway. Using the student's work, the teacher explained some } \\ & \text { missing steps then ask the students to accomplish the initial work. Another } \\ & \text { student tried continuing the work but still undone. The teacher again asked his }\end{aligned}$




\begin{tabular}{ll}
\hline $\begin{array}{l}\text { Teaching } \\
\text { episodes }\end{array}$ & Teacher's practices \\
\hline
\end{tabular}

student to accomplish it. A different student came and finished the work. The teacher ended the lesson by giving the task 3-5 as the homework.

Episode 2

The teacher began the lesson by explaining the position of two lines on the board when determining their distance, i.e., the two lines are perpendicular, the two lines intersect and perpendicular and the two lines intersect but not perpendicular. The teacher asked one of the students to solve task 3 while showing the task on the main screen. It is to determine the distance of line AC and line DE in cube ABCD.EFGH.

The student wrote his work on the board. On the student's work, the teacher explained to the whole class how do determine the distance. The teacher displayed and manipulated GeoGebra (Figure 5) to prompt students thinking the ways to determine the distance. It aimed to show that any lines on the plane DEG can represent the line DE. A student came forward to explain further how to determine the distance using Figure 5 on the screen and draw a cube on the board. The teacher explained the students work again to the whole class.

The teacher posed a question, are the segment MN and JK equal? The students have different responses, some disagreed, and the others agreed. To facilitate the discussion, the teacher drew a plane and a line above it on the board to further explore the question. A different student volunteered to explain his answer and showed in the GeoGebra that the segment is equal.

Episode 3

Episode 4

In this lesson, the students were divided into some groups. Each group has one laptop/netbook, and GeoGebra was installed. The teacher began the lesson by showing the task 1 which consist of four parts on the screen then discuss them with students. It is a closed discussion where the teacher asks and explain then the student listen and answer. The discussion aimed to explain the criteria of the distance of a line to plane. In the teacher's explanation, the teacher used the cube in GeoGebra for example to draw some segments. The teacher offered the chance for the students to come forward and construct the distance on GeoGebra for part (d). A student came forward and used the teacher's laptop to draw the distance of line EA to plane BDHF.

The teacher proceeded to task 2 (Figure $3 b$ ) to be discussed and solved in the group. The teacher did not walk by in the students as they were discussing the task on the GeoGebra. The GeoGebra file of task 2 had been distributed to each group. The teacher asked the representative of one group to come forward and construct the distance on the main screen. A student successfully showed the distance then the teacher asked who can evaluate the distance on the board. Another student solved the task 2 on the board. The teacher re-explained the student's work then proceed to task 3 .

The teacher gave some minutes to discuss task 3 in the group while he walked by the group. However, the teacher just passed by the group without an intense check on students' work. One student came forward and constructed the distance on the main screen. The teacher challenged other students to calculate the distance on the board. The students seemed doubt to came then the teacher himself explain the distance since the time was nearly over. The teacher ended the lesson by altering the students to work in the group for task 4 and task 5 .

In this lesson, the teacher asked the group to discuss task 5. There was no projector since the students moved to the new room. The discussion setting was similar to the previous lesson, and each group has one laptop/netbook. The teacher just passed by the group without checking or questioning students' work. A representative of the group came forward to solve the task on the board. Once the student finished his work, the teacher asks other groups to respond and offer 


Teaching
episodes $\begin{aligned} & \text { Teacher's practices } \\ & \text { alternative answers. While waiting for the response, the teacher reminded the } \\ & \text { concept of the distance of a line to plane by drawing a plane and a line. No } \\ & \text { response yet from the students, the teacher extended his explanation by drawing } \\ & \text { and showing the distance. } \\ & \text { A student came forward to continue the teacher's work but still has not got } \\ & \text { the final answer. The teacher explained the student's work again and invited } \\ & \text { different students to find the final result. Another student came forward and } \\ & \text { successfully got the result. The teacher once more asked if there are other ways } \\ & \text { of solving the task 5. } \\ & \text { A student came forward and wrote her different solution. The solution was } \\ & \text { more efficient and effective than the way teacher initiated. However, the teacher } \\ & \text { disagreed on her alternative solution as the non-standard procedure was used. } \\ & \text { The student could not convince the teacher about the procedure she chose. To } \\ & \text { resolve the situation, the teacher asked the researchers' opinion. The conclusion } \\ & \text { was that she used the proper procedure, so the alternative solution was granted. }\end{aligned}$
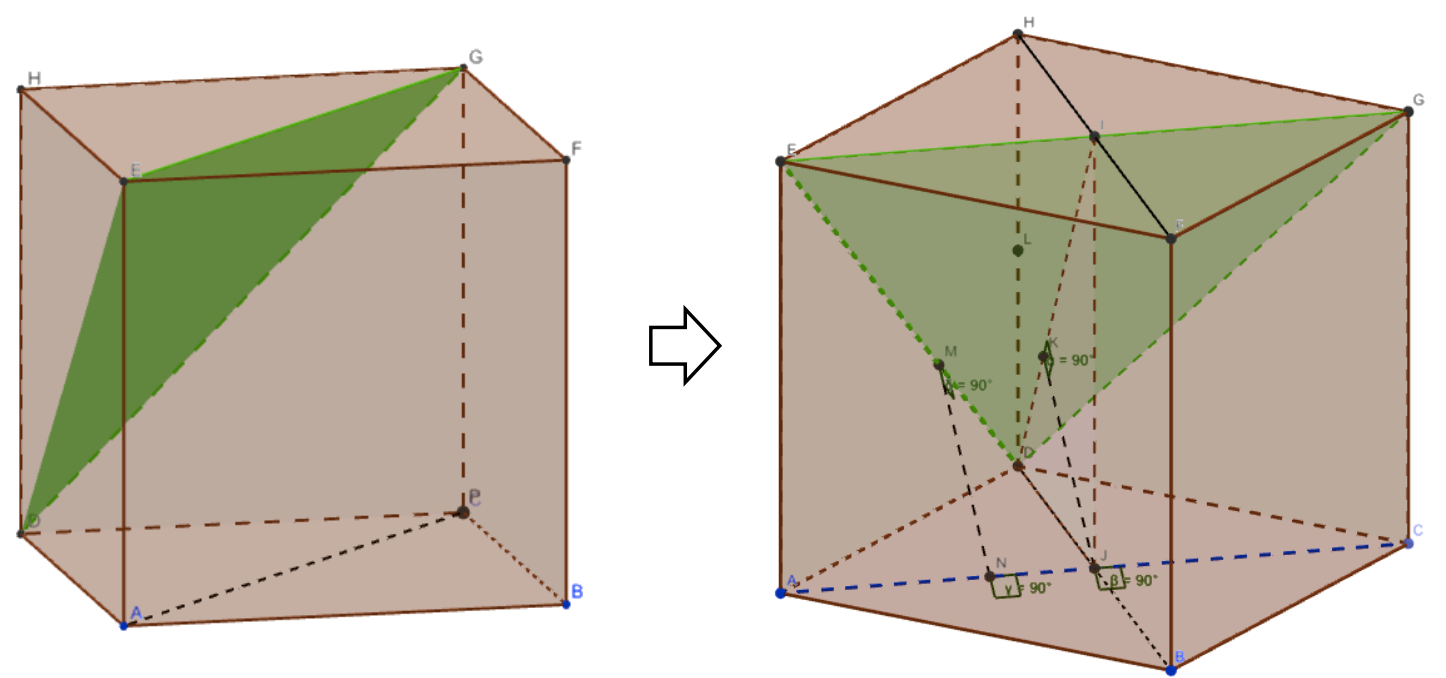

Figure 5. Task 3 to determine the distance of line AC to line DE in episode 2 of MT1 lesson

Table 2. MT2 lessons with GeoGebra

\begin{tabular}{ll}
\hline $\begin{array}{c}\text { Teaching } \\
\text { episodes }\end{array}$ & Teacher's practices \\
\hline Episode 1 & $\begin{array}{c}\text { The teacher began the lesson by drawing a cube in GeoGebra showing } \\
\text { in the main screen and asked the students to draw it in their GeoGebra. Within } \\
\text { the cube, the teacher drew two lines and showed that they intersect and are } \\
\text { perpendicular using the angle feature. It is to show the students that } \\
\text { GeoGebra gives much help for something that could not be readily identified } \\
\text { with a manual draw or other physical tools. Sometimes the teacher forgot and } \\
\text { did know some features and asked the help from the researchers. The teacher } \\
\text { reviewed the distance of a point to the planes through GeoGebra in a central } \\
\text { screen format and identified the perpendicular line to the plane. } \\
\text { A short explanation was given to introduce the concept of the distance } \\
\text { of a line to line on the board. The teacher drew two parallel lines and connect } \\
\text { them with a perpendicular line as the distance then cube ABCD.EFGH was } \\
\text { drawn. Using the cube, the teacher explained the lines that intersect, parallel, } \\
\text { and perpendicular. }\end{array}$ \\
\hline
\end{tabular}




\begin{tabular}{|c|c|}
\hline $\begin{array}{l}\text { Teaching } \\
\text { episodes }\end{array}$ & Teacher's practices \\
\hline & $\begin{array}{l}\text { After that, the teacher showed the task } 1 \text { on the screen which has been } \\
\text { made in GeoGebra then in a closed discussion (teacher explain and ask then } \\
\text { students give short responses) the teacher explain the task } 1 \text {. The task was } \\
\text { similar to Figure 3a. For example, the distance of line EH to line CG. The } \\
\text { line feature was used by the teacher to extend the EH and CG so the students } \\
\text { can notice the position of the two lines. The students were also asked to show } \\
\text { the task on their GeoGebra. } \\
\text { The time was over then she gave task } 2 \text { as the homework. The teacher } \\
\text { reminded that the students should solve the task } 2 \text { by showing them in } \\
\text { GeoGebra and working them manually in the students' book. In the next } \\
\text { meeting, the task would be discussed. }\end{array}$ \\
\hline
\end{tabular}

Episode 2

Episode 3

The teacher invited the students to represent their work on task 2 (Figure 4) before the class. A female student came forward to show her work on GeoGebra and determine the distance on the board. She was also required to explain her work to the whole class. The explanation on the board was linked to the GeoGebra. With the feature of angle measure and perpendicular line, she has accomplished the task 2 on GeoGebra.

Then the teacher drew a similar cube on the board to explain the alternative ways of determining the distance between two parallel lines. The teacher continued with part 2 of the task using the cube on the board, determining the distance of line $\mathrm{AH}$ to line BD. A short explanation on the difference of two intersecting lines which are not perpendicular and perpendicular was given on the board. The teacher explained how to constructed the distance of the two lines on the board and suggested the students try on GeoGebra.

The teacher asked a student who has worked the part 2 on GeoGebra to show on the screen. The teacher used the worked GeoGebra to further explain the distance by some drags and manipulations. The teacher asked whether or not the students got the answer on manual work. Some students informed the answer to the teacher. The teacher was not sure some students understand part 2, so she had another explanation on the board and linked to GeoGebra. The teacher ended the lesson by giving the task 3 which will be discussed in the next meeting.

In this lesson, the teacher invited the students to show their works of task 3 on the screen and determine the distance on the board. Task 3 had a similar format to the previous task. It comprised three parts. A student showed and explained her work (task 3 part a) on screen then calculate the distance on the board. After the student was done, the teacher re-explained the answer shortly on the board and screen then asked other students whether or not they got the answer. The teacher also offered other students who have other solution to come forward, but none did. The teacher walked by the students to check their work on GeoGebra and books. Part b and part c of task 3 were managed similarly.

Before discussing how the teachers use digital technology in teaching mathematics and the change of their practices from without-technology to with-technology, we think it is important to shortly take a look at the tasks used by the teachers. We tried to link the tasks used and activity format of the lessons. However, teachers' task is not the focus of the current research. The mathematics tasks (Figure 1 and Figure 2) designed by MT1 and MT2 in the group with the tasks used in the lessons (e.g., Figure 3 and Figure 4) are quite different. The first provided the 
students with a sequence of activities. Meanwhile, the latter directly have the students got the answer. The tasks used by MT1 and MT2 are commonly found in Indonesia mathematics textbooks as the exercises. In the interview, the teacher confirmed that the tasks were directly adopted from the textbooks. The design of such tasks has not yet exploited the tool's pedagogical potential as the teachers focus the students' attention on solving the task on the board. The tool was only to help to see the other representation of the mathematics objects. Laborde (2002) had earlier noted in her longitudinal study that several teachers initially used technology as a visual aid. The case confirmed that the design of tasks and lesson or teaching, in general, are interrelated (Drijvers, 2015). We did not further clarify why the teachers adopt the tasks in the textbook or did not extend or at least follow the tasks they made in the group. We would wisely guest that the teachers' fewer experiences in a technology-based mathematics classroom influence the decisions they made in using the tasks.

The episodes described in Table 1 and Table 2 are the primary basis to draw initial conjectures on how the novice teachers use digital technology in teaching mathematics in the lens of instrumental orchestration (Drijvers et al., 2010) and didactic tetrahedron unfolded (Hollebrands \& Okumuş, 2018; Hollebrands \& Lee, 2016). The first will reveal teachers' instrumental orchestration and describe the changes in teachers' practices. The latter will highlight the teachers' focus.

\section{Teachers' instrumental orchestration}

Drawing from the findings from Drijvers et al. (2014), we identified and compared the whole class orchestrations of MT1 and MT2 in Table 3. In each orchestration, the didactical configuration (DC) and exploitation modes (EM) are included.

Table 3. Teachers' instrumental orchestration

\begin{tabular}{|c|c|c|}
\hline $\begin{array}{l}\text { Instrumental } \\
\text { orchestrations }\end{array}$ & MT1 & MT2 \\
\hline Technical-demo & $\begin{array}{l}\text { EM: Teacher did not demonstrate the } \\
\text { tool techniques } \\
\text { DC: LCD projector (one central } \\
\text { screen), classical classroom } \\
\text { arrangement, the teacher has access to } \\
\text { GeoGebra }\end{array}$ & $\begin{array}{l}\text { EM: Teacher introduced the } \\
\text { features of GeoGebra and } \\
\text { demonstrate the tool techniques, } \\
\text { e.g., draw a line } \\
\text { DC: LCD projector (one central } \\
\text { screen), classical classroom } \\
\text { arrangement, the teacher has access } \\
\text { to GeoGebra }\end{array}$ \\
\hline Explain-the-screen & $\begin{array}{l}\text { EM: The teacher showed the tasks in } \\
\text { the screen and explained them in a } \\
\text { closed discussion with students. The } \\
\text { exploitation of tools'pedagogical } \\
\text { potential was unidentified } \\
\text { DC: Similar to the technical demo }\end{array}$ & Similar to the MT1 \\
\hline Link-screen-board & $\begin{array}{l}\text { EM: The teacher explained the topic } \\
\text { on the board at the beginning of the } \\
\text { lesson. The teacher did not link the } \\
\text { screen and the board } \\
\text { DC: teacher's access to GeoGebra, LCD } \\
\text { projector, visible blackboard, and } \\
\text { screen position }\end{array}$ & Similar to the MT1 \\
\hline Discuss-the-screen & Similar to explain-the-screen & Similar to explain-the-screen \\
\hline Spot-and-show & $\begin{array}{l}\text { EM: Some students solved the task on } \\
\text { the board, the teacher provided }\end{array}$ & $\begin{array}{l}\text { EM: Some students explained } \\
\text { his/her works on GeoGebra and }\end{array}$ \\
\hline
\end{tabular}




\begin{tabular}{|c|c|c|}
\hline $\begin{array}{l}\text { Instrumental } \\
\text { orchestrations }\end{array}$ & MT1 & MT2 \\
\hline & $\begin{array}{l}\text { feedback/and re-explained the } \\
\text { students' work on the board to the } \\
\text { whole class, and students' reasoning } \\
\text { was not exposed to the floor. } \\
\text { DC: The teacher has not accessed } \\
\text { students' work on the task, LCD } \\
\text { projector, visible screen position, } \\
\text { classical classroom arrangement }\end{array}$ & $\begin{array}{l}\text { board, the teacher gave } \\
\text { feedback/and explained the } \\
\text { student's work or another solution } \\
\text { on the board, and students' } \\
\text { reasoning was not exposed to the } \\
\text { floor. } \\
\text { DC: The teacher has access to } \\
\text { students' work on the task, LCD } \\
\text { projector, visible screen position, } \\
\text { classical classroom arrangement }\end{array}$ \\
\hline Sherpa-at-work & $\begin{array}{l}\text { EM: No requests or instructions from } \\
\text { teacher to use GeoGebra } \\
\text { DC: the teacher has access to } \\
\text { GeoGebra but not to students' work on } \\
\text { the task, LCD projector, visible screen } \\
\text { position, classical classroom } \\
\text { arrangement }\end{array}$ & $\begin{array}{l}\text { EM: Some students used GeoGebra } \\
\text { to show their work displayed on the } \\
\text { main screen, the teacher asked } \\
\text { students to work the task on } \\
\text { GeoGebra or check their work (no } \\
\text { specific actions requested by the } \\
\text { teacher) } \\
\text { DC: Teacher has access to } \\
\text { GeoGebra and students' work on } \\
\text { the task, LCD projector, visible } \\
\text { screen position, classical classroom } \\
\text { arrangement }\end{array}$ \\
\hline Work-and-walk-by & $\begin{array}{l}\text { EM: The students worked the task in a } \\
\text { group, no interaction and discussion, } \\
\text { the teacher did not monitor the } \\
\text { progress } \\
\text { DC: Students in the group with one } \\
\text { laptop, the teacher, did not walk by in } \\
\text { the classroom. }\end{array}$ & $\begin{array}{l}\text { EM: The students worked } \\
\text { individually, no interaction and } \\
\text { discussion, the teacher did not } \\
\text { monitor the progress } \\
\text { DC: Each student used GeoGebra } \\
\text { on her/his laptop, the teacher } \\
\text { walked by in the classroom to } \\
\text { check students' work. }\end{array}$ \\
\hline
\end{tabular}

\section{Teachers' focus}

The findings from Hollebrands and Lee (2016) as the point of departure, we investigated the teachers' focus when using GeoGebra in teaching mathematics. Table 4 shows the focus of MT1 and MT2.

Table 4. Teachers' focus on digital technology-based mathematics classroom

\begin{tabular}{|c|c|c|}
\hline Teacher & Classroom practices & Category \\
\hline \multirow[t]{4}{*}{ MT1 } & $\begin{array}{l}\text { Episode 1: The teacher asked the students' responses or } \\
\text { answers on the task, e.g., are the lines perpendicular? Is the } \\
\text { line EF represent the distance of the line EH to FG? } \\
\text { Teacher's explanation about the distance of two lines }\end{array}$ & Focus on mathematics \\
\hline & $\begin{array}{l}\text { Episode 2: The teacher asked whether or not the segment } \\
\text { MN and JK equal while pointing the segments to the screen } \\
\text { but the further explanation about the segments was done in } \\
\text { the board }\end{array}$ & Focus on mathematics \\
\hline & $\begin{array}{l}\text { Episode 3: The teacher provided a chance for the students to } \\
\text { construct the distance of a line to a plane using GeoGebra on } \\
\text { the main screen. }\end{array}$ & $\begin{array}{l}\text { Focus on technology to } \\
\text { notice mathematics }\end{array}$ \\
\hline & $\begin{array}{l}\text { Episode 4: The teacher has not accessed students' work } \\
\text { using GeoGebra in the group. The teacher explained the } \\
\text { distance or provide feedback on students' work on the board } \\
\text { or without linking to the GeoGebra }\end{array}$ & Focus on mathematics \\
\hline
\end{tabular}




\begin{tabular}{lll}
\hline Teacher & \multicolumn{1}{c}{ Classroom practices } & \multicolumn{1}{c}{ Category } \\
\hline MT2 & $\begin{array}{l}\text { Episode 1: The teacher required students to solve the task on } \\
\text { GeoGebra and book. The teacher used line feature to have }\end{array}$ & Focus on mathematics \\
the students noticed the position of two lines & & \\
& Episode 2: The teacher used the worked GeoGebra to further \\
explain the distance by some drags and manipulations & \\
& Episode 3: The students show their works of task 3 on the \\
screen and determine the distance on the board & \\
\hline
\end{tabular}

Table 3 shows that there are many exploitation modes which cannot be fulfilled from the teachers' instrumental orchestrations. In technical-demo orchestration, MT1 did not demonstrate the tool techniques which relate to the task. In explain-the-screen orchestration, MT1 and MT2 only showed the task and had closed discussion with the students regarding the task. However, the pedagogical potential of the GeoGebra which support the students to solve the task has not been exploited. In link-screen-board orchestration, MT1 and MT2 explained the sample of the task (worked example) on the board, but they did not link to the screen. Since the teachers did not explain the task on the screen, the other two orchestrations (link-the-screen and discuss-thescreen) could not be fulfilled. In the first three orchestration, the teacher is meant to guide the interactions in an initiation-response-evaluation pattern (Drijvers et al., 2010). In this case, the teacher prepares the students to use the tools and learn mathematics.

In the latter orchestration, i.e., discuss-the-screen, spot-and-show and sherpa-at-work the students should have the opportunity to react and more input in learning (Drijvers et al., 2010). In discuss-the-screen orchestration, students' work on GeoGebra or teachers' work should be used to encourage students' response or reactions. However, the exploitation mode is not identified in the teachers' practices. In spot-and-show orchestration, the students explained their works on GeoGebra and the board and the teachers provided feedback. However, students' reasoning as the basis for further discussion on the task was not brought to the fore. In sherpaat-work and work-and-walk-by orchestration, MT1 did not manage the group work. The students were given the time to work the task in the group, but the teacher did not lead the group to do specific actions and monitor the progress of students' work. MT2 did ask the students to work the task on GeoGebra and book but did not manage to support the students solving the task individually in intense discussion.

In the teachers' practices (Table 3), we mostly observed non-technology orchestrations, i.e., explanatory and board-instruction orchestration. It is a traditional setting of teaching where the teacher explains the task to the whole class (Drijvers et al., 2014). The explanation has no apparent connection to the use of digital technology. The teachers brought mostly the same routines to their technology classroom as their regular lesson in non-technology teaching. For example, the ways teachers explain the topic at the beginning of the lesson and introduce the task. In the regular lesson without-technology, the teachers explain the topic on the board in expository or lecturing mode. Episode 1 and episode 2 of MT1 (Table 1) and episode 1 of MT2 (Table 2) confirmed this similarity. After the teachers explain the topics, they provide worked example in regular lesson following by the exercises on the book or the board. In a withtechnology lesson, the teachers just moved the task on the screen and had the same way of explaining the worked sample of the task then left the students the remaining task as the exercises.

The use of digital technology in the observed teachers' practices did not transform or change mathematical activity. It is in contrast to the roles of the digital technology (GeoGebra) that 
should contribute to the mathematical activity (Sutherland, 2005). The board dominates the teachers' observed orchestration and their regular lesson instead of the tools and their combination. Prior researches (e.g., Bozkurt \& Ruthven, 2015; Drijvers et al., 2014; Monaghan, 2004) have also confirmed this finding. De Villiers (2006) argued that the use of digital technology in the classroom would be a pitfall when the teachers use it as a glorified blackboard and do not fundamentally change the traditional style of teaching.

Table 4 reveals that the teachers have a different focus on teaching mathematics using digital technology. MT1 focused only on mathematics as he ruled out the tools. The teacher used the board more frequently to explain worked example of the task or provided feedback on students' work without linking to the screen. The focus of MT1 relates to his orchestration where the pedagogical features of the GeoGebra have not to be exploited. MT2 urged her students to work the task on GeoGebra and book. The students who came forward to solve the task were also required to show it on the screen and do on the board. MT2 also in some moments used GeoGebra features, e.g., dragging and extending segments to lead students' attention on mathematics objects. For those cases, MT2 tried to focus on mathematics through the use of technology. We used the word 'tried' to indicate that MT2 has no specific requests or prompts to the students using the features of GeoGebra and the teaching she orchestrated was not fully instrumented by the tool. For clarity reason, we use Figure 6 (tetrahedron unfolded and its coding) made by Hollebrands and Lee (2016) as the illustration to the current findings. Figure $6 \mathrm{a}$ and $6 \mathrm{~b}$ respectively illustrate the focus of MT2 and MT1.
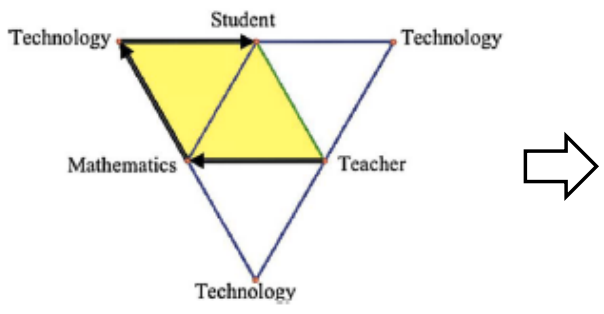

(a)

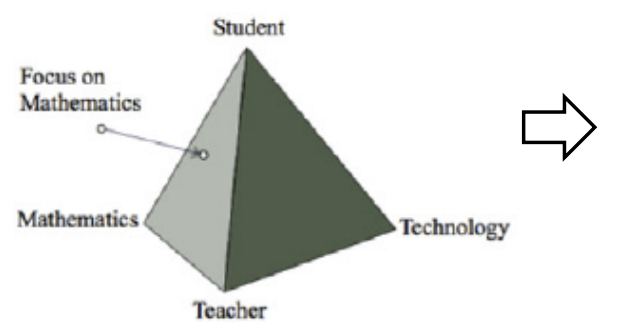

(b)
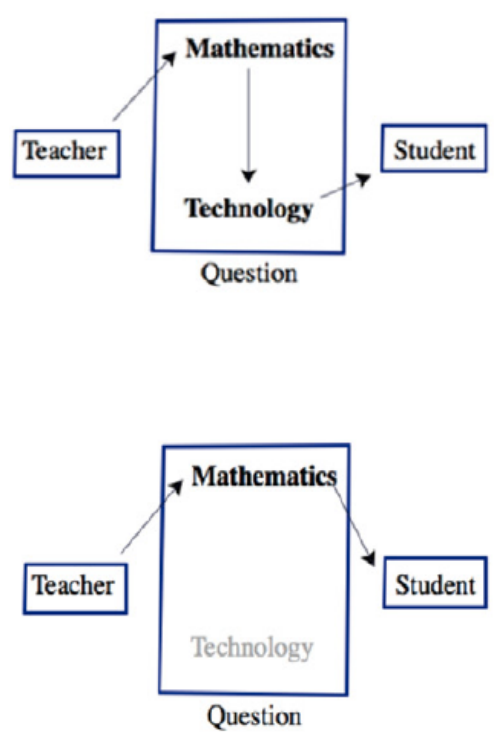

Figure 6. The teachers' focus on digital technology-based mathematics teaching (Hollebrands \& Lee, 2016)

In this research, we try understanding the novice teachers' practices in technology-rich mathematics teaching. It did not 'judge' whether or not the teachers perform well in their new routines of teaching using digital technology. The teachers' orchestration which is not different from their regular lesson and focuses to mathematics instead of both mathematics and technology gives a whole picture of the novice teachers' practices. The whole pictures will be a 
salient aspect which contributes to the design and implementation of TPD program and mathematics teacher education.

The findings of the current research imply that the orchestration of the artifacts, teachers' focus on mathematics and technology, and the activity format of technology-based mathematics classroom should be emphasized in the TPD program. The intervention of the researchers in designing digital technology-related mathematics task and teachers' reflections after classroom teachings are essential cases to develop teachers' routines or orchestration of technology-rich mathematics teachings. The limitation of the current research is regarding the limited number of observed lessons. The changes in teachers' practices from without-technology to withtechnology would require more episodes of the lesson to fulfill or be compatible with the orchestrations found in the prior researches (e.g., Drijvers et al., 2014). Further researches would be necessary to investigate the changes in teachers' practices and its related factors such as the mathematics tasks used by the teachers from without-technology to with-technology in mathematics teachings.

\section{Conclusion}

The research found that the observed teachers' orchestrations are mostly non-technology orchestrations, i.e., explanatory and board-instruction orchestration. The board has been used frequently without linking to the screen. The tools' pedagogical roles have not been exploited in the ways that the technology support students in learning mathematics. The use of digital technology does not substantially change the mathematical activity as seen in the ways the teachers orchestrate the practices. The teachers have a different focus in using digital technology to teach mathematics. One merely focuses on mathematics as he used the board more frequently without linking to the screen. For this case, the practices teacher orchestrated relate to his focus on mathematics. Another teacher tried focusing on mathematics through the use of technology but with limited exploitation of the tools. The research concludes that old-fashioned classroom practices can be the pitfall for using digital technology in the mathematics classroom since the activity format of the new learning environment is unchanged and affected by regular lesson. The findings suggest that related factors, such as the design of tasks and old-fashioned classroom practices, to the pitfalls of technology-rich mathematics environment and the relation of digital tools to specific mathematics activities, should be considered in teachers' professional development on the integration of digital technology in mathematics teachings.

\section{Acknowledgment}

We want to express our gratitude to the Directorate of Research and Community Service Ministry of Research and Higher Education for funding this year 2018 community service program in the form of short period teachers' professional development of mathematics teachers. The program did support and develop teachers practices of digital technology integration in mathematics teaching.

\section{References}

Aydos, M. (2015). The impact of teaching mathematics with geogebra on the conceptual understanding of limits and contınuity: The case of Turkish gifted and talented students. (Doctoral), Bilkent University, Retrieved from http://www.thesis.bilkent.edu.tr/0006980.pdf 
Ratnasari, D., Wahyu, K., \& Mahfudy, S.

Bozkurt, G., \& Ruthven, K. (2015). Expert and novice teachers' classroom practices in a technological environment. Paper presented at the ERME 9 - Ninth Congress of the European Society for Research in Mathematics Education, Prague, Czech Republic.

Brown, J. P. (2015). Complexities of digital technology use and the teaching and learning of function. Computers \& Education, 87, 112-122.

Brown, J. P. (2017). Teachers' perspectives on changes in their practice during a technology in the mathematics education research project. Teaching and Teacher Education, 64, 52-65.

Chan, Y.-C., Leung, A., \& Ong, D. M. Y. (2016). Feedback and discrepancies of a physical toolkit and a digital toolkit: Opportunities and pitfalls for mediating the concept of rotational symmetry. In A. Leung \& A. Baccaglini-Frank (Eds.), Digital Technologies in Designing Mathematics Education Tasks: Potential and Pitfalls (Vol. 8): Springer.

Choi, K. S. (2010). Motivating students in learning mathematics with GeoGebra. Computer Science Series, 8(2), 65-76.

Clark-Wilson, A., Aldon, G., Cusi, A., Goos, M., Haspekian, M., Robutti, O., \& Thomas, M. O. J. (2014). The challenges of teaching mathematics with digital technologies: The evolving role of the teacher. Paper presented at the Proceedings of the Joint Meeting of PME 38 and PME-NA 36, Vancouver, Canada.

Cobb, P., \& Whitenack, J. W. (1996). A method for conducting longitudinal analyses of classroom video recordings and transcripts. Educational Studies in mathematics, 30(3), 213-228.

De Villiers, M. (2006). Some pitfalls of dynamic geometry software. Learning and Teaching Mathematics, 4(2), 46-52.

Doruk, B. K., Aktümen, M., \& Aytekin, C. (2013). Pre-service elementary mathematics teachers' opinions about using GeoGebra in mathematics education with reference to 'teaching practices.' Teaching Mathematics and its Applications: An International Journal of the IMA, 32(3), 140-157.

Drijvers, P. (2015). Digital technology in mathematics education: Why it works (or doesn't). In Selected regular lectures from the 12th international congress on mathematical education (pp. 135-151): Springer, Cham.

Drijvers, P., Doorman, M., Boon, P., Reed, H., \& Gravemeijer, K. (2010). The teacher and the tool: Instrumental orchestrations in the technology-rich mathematics classroom. Educational Studies in mathematics, 75(2), 213-234.

Drijvers, P., Tacoma, S., Besamusca, A., van den Heuvel, C., Doorman, M., \& Boon, P. (2014). Digital technology and mid-adopting teachers' professional development: A case study. In A. Clark-Wilson, O. Robutti, \& N. Sinclair (Eds.), The mathematics teacher in the digital era (pp. 189-212). Dordrecht: Springer.

Hähkiöniemi, M. (2013). Teacher's reflections on experimenting with technology-enriched inquiry-based mathematics teaching with a preplanned teaching unit. The Journal of Mathematical Behavior, 32(3), 295-308.

Hollebrands, K., \& Okumuş, S. (2018). Secondary mathematics teachers' instrumental integration in technology-rich geometry classrooms. The Journal of Mathematical Behavior, 49, 82-94.

Hollebrands, K. F., \& Lee, H. S. (2016). Characterizing questions and their focus when pre-service teachers implement dynamic geometry tasks. The Journal of Mathematical Behavior, 43, 148-164.

Kendal, M. (2001). Teaching and learning introductory differential calculus with a computer algebra system. (Ph.D.), University of Melbourne,

Laborde, C. (2002). Integration of technology in the design of geometry tasks with Cabri-geometry. International Journal of Computers for Mathematical Learning, 6, 283-317.

Laborde, C. (2007). The role and uses of technologies in mathematics classrooms: Between challenge and modus vivendi. Canadian Journal of Math, Science \& Technology Education, 7(1), 68-92.

Leung, A. (2011). An epistemic model of task design in dynamic geometry environment. ZDM, 43(3), 325-336.

Leung, A. (2016). Exploring techno-pedagogic task design in the mathematics classroom. In A. Leung \& A. Baccaglini-Frank (Eds.), Digital Technologies in Designing Mathematics Education Tasks: Potential and Pitfalls (Vol. 8, pp. 3-16): Springer.

Monaghan, J. (2004). Teachers' activities in technology-based mathematics lessons. International Journal of Computers for Mathematical Learning, 9(3), 327-357. 
Mukiri, M. I. (2016). Feasibility of using GeoGebra in the teaching and learning of geometry concepts in secondary schools in Kajiado county, Kenya. (Doctoral), Kenyatta University, Retrieved from https://bit.ly/2yFMMjg

Olive, J., Makar, K., Hoyos, V., Kor, L., Kosheleva, O., \& Sträßer, R. (2010). Mathematical knowledge and practices resulting from access to digital technologies. In C. Hoyles \& J. B. Langrange (Eds.), Mathematics education and technology_rethinking the terrain (pp. 133-177). New York: Springer.

Olsson, J. (2017). GeoGebra, enhancing creative mathematical reasoning. (Doctoral), Umeå Universitet, Retrieved from http://www.diva-portal.org/smash/get/diva2:1085687/FULLTEXT01.pdf

Rutherford, T., Long, J. J., \& Farkas, G. (2017). Teacher value for professional development, selfefficacy, and student outcomes within a digital mathematics intervention. Contemporary Educational Psychology, 51, 22-36.

Ruthven, K. (2009). Towards a naturalistic conceptualization of technology integration in classroom practice. Education \& Didactique, 3(1), 131-159.

Ruthven, K. (2012). The didactical tetrahedron as a heuristic for analyzing the incorporation of digital technologies into classroom practice in support of investigative approaches to teaching mathematics. ZDM Mathematics Education, 44, 627-640.

Sullivan, P., Clarke, D., \& Clarke, B. (2012). Teaching with tasks for effective mathematics learning. New York: Springer Science \& Business Media.

Sutherland, R. (2005). ICT and learning mathematics: Developing a community of practice. Mathematics in School, 34(4), 4-5.

Tall, D. (1986). Using the computer as an environment for building and testing mathematical concepts: a tribute to Richard Skemp. Retrieved from https://homepages.warwick.ac.uk/staff/David.Tall/pdfs/dot1986h-computer-skemp.pdf

Tapan, S. (2003). Integration of ICT in the teaching of mathematics in situations for treatment of difficulties in proving. Paper presented at The 3rd Conference of the European Society for Research in Mathematics Education (CERME 3), Bellaria, Italy.

Trouche, L. (2004). Managing complexity of human/machine interactions in computerized learning environments: Guiding students' command process through instrumental orchestrations. International Journal of Computers for Mathematical Learning, 9, 281-307.

Zengin, Y. (2017). The effects of GeoGebra software on pre-service mathematics teachers' attitudes and views toward proof and proving. International Journal of Mathematical Education in Science and Technology, 48(7), 1002-1022. Doi:10.1080/0020739X.2017.1298855 